\title{
THE EXISTENCE OF HEART IN HADITH REVIEW
}

\author{
M. Yusuf Assagaf ${ }^{1}$ \\ Abustani Ilyas ${ }^{2}$ \\ Tasmin Tangngareng ${ }^{3}$ \\ La Ode Ismail Ahmad ${ }^{4}$
}

Alauddin State Islamic University of Makassar, Indonesia ${ }^{1,2,3,4}$

yusufsegaf2@gmail.com¹, abustani.ilyas@uin-alauddin.ac.id², tasmin.tangngareng@uin-alauddin.ac.id ${ }^{3}$, laode.ismail@uin-alauddin.ac.id ${ }^{4}$

\begin{abstract}
This paper discussed hadith related to the existence of the heart with main topics 1) the quality of the hadith and 2) content. The results of this study indicate that the existence of heart hadith based on the transmission consists of 16 lines (sanad) which are spread in the book of 9 imams (al-kutub al-tis'ah) and narrated in meaning. In addition, 1) the existence of heart hadith has good quality, both in terms of the sanad and matan, and 2) the hadith shows the existence of the heart as a treasury of abstract issues, such as; beliefs, feelings, disbelief, and others. In addition, the liver is an organ that plays a role in giving a command to all body organs to move. This paper is expected to understand the broader community that the heart has a vital role in the excellent condition of the body and human actions, especially to achieve the best level as human beings mentioned in QS al-Hujurat(49:13).
\end{abstract}

Keywords: Existence; Heart; al-Qalb

\section{INTRODUCTION}

The Prophet, as the noblest human being, has a mission to convey the risalahilahi (the letter of God). Risalahilahi is the revelation in the form of the Qur'an and hadith. Al-Qur'an and hadith are sources of law for Muslims. However, according to Muslim scholars, both of them are different in quality. The whole Qur'an is recognized its existence ( $q$ at ${ }^{\prime} \cdot \bar{i}$ al-dilalah), while the hadith generally is still an estimation of its existence (zanni al-dilālah). Therefore, a new hadith can be true after clarifying it through research on its sanad and matan. The existence of hadiths is considered when the hadits are contained in the books of sahihain (Șahịh alBukhäri and Sahīh. Muslims), because the majority of scholars apply the requirements in selecting hadith, namely the continued sanad, the narrators are fair and strong in maintenance (dâabit), not having illat and not contradicting.

In terms of the content of the discussion, the Qur'an and hadith contain discussions about worship, law, and mu'amalah. One of the contents conveyed by both of them is a matter of the heart. For example, in the Qur'an, it is stated that it turns out that bad deeds can cover the heart, as Allah says in QS. al-Mutaffifin/83: 14, as follows.

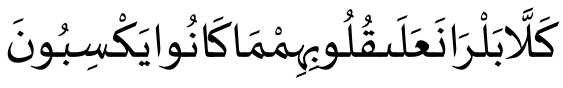


The translation:

"Never! Even what they do has covered their hearts."

The verse explains those who deny Allah's verses and commit sins, based on that their hearts are closed because of the many sins they have committed. Al-Wahidi explains the verse's meaning that their hearts are defeated (by lust) until they are closed and darkened because of the immoral actions, like rust (on iron) that covers the heart. ${ }^{2}$ Even though immoral acts can cause black spots on the heart, it turns out that the heart can be cleaned, namely by repenting and avoiding disobedience, as in the QS. al-Furqan $(25 ; 69)$ that;

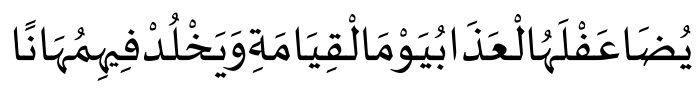

The translation;

"Except for those who repent and believe in Allah and do good deeds; then their evil is replaced with good. Allah is the Most Forgiving, Most Merciful."

These verses show that the heart has a vital role in the structure human body structure. Therefore, the author is interested in studying the existence of the heart in hadith review as the highest interpretation of the Qur'an. ${ }^{3}$

\section{THEORETICAL OVERVIEW}

\section{A. Definition of Heart}

Heart based on Kamus Besar Bahasa Indonesia (KBBI) has much meanings, namely; 1 . The part of the belly, which is red-blackish, is located on the right side of the large stomach, which helps take food juices in the blood and producing bile, 2. Meat from the liver as food (slaughtered animal liver), 3. Heart, 4. Something on the human body is considered a place for all inner feelings and a place of understandings (feelings), 5. What is spiritually felt, 6. The nature (character) of the human spirit, 7. The inner part. ${ }^{4}$ From those meanings, it indicates the heart based on its shape, function, and location.

Heart in the Arabic language is generally referred to the word القلب. Muhammad Fu'ad al-Baqi in Mu'jam al-Mufahras li Alfaz the Qur'an explains that the word al-qalb with various changes in its form is mentioned approximately 130 times in the Qur'an which is spread over 42 surah and 112 verses, while the varied meaning and purposes based on the context of the discussion of a verse. ${ }^{5}$

\footnotetext{
${ }^{1}$ Kementerian Agama RI, Al-Qur'an dan Terjemahnya,(Cet. I; t.t., PT Tiga Serangkai Pustaka Mandiri, 1430 H / 2009 M), h. 588.

${ }^{2}$ See Abū al-Hasan 'Ali bin Ahmad bin Muhamma bin 'Ali al-Wāhiđì al-Naisābūrì, Al-Wajīz fí Tafsìr al-Kitāb al-'Azīz, (Cet. I; Bairūt: Dār al-Qalam, 1415 H), h. 1183.

${ }^{3}$ Kementerian Agama RI, Al-Qur'an dan Terjemahnya, h. 366.

${ }^{4}$ Kementerian Pendidikan Indonesia, Kamus Besar Bahasa Indonesia,(Cet. XVI; Jakarta: Pusat Bahasa, 2008 M), h. 532.

${ }^{5}$ See Muhammad Fu'ad 'Abd al-Baqi, Al-Mu'jam al-Mufahras li Alfaz al-Qur'an al-Karim, (Kairo: Dar al-Kutub al-Mișriah, 1364 H), h. 549-551.
} 
The word al-qalb is a masdar form of the root word of qalaba-yaqlubu-qalban. Ibn Faris explained that the word al-qalb, which consists of the letters qaf, lam and $b a^{\prime}$ has 2 basic meanings, namely; yadullu 'ala khalis syai' wa sharifih (the core/center of something and its glory) and yadullu 'ala radd syai' min jihhah ila jihhah (the change of something from one side to the other). ${ }^{6}$ Meanwhile, according to Ibn Manzur, the word al-qalb shows the meaning of changing something from one direction to another. ${ }^{7}$ The explanation shows that the meaning of the word alqalb is the core/center of something and has nobility, while the situation is fluctuating.

The heart which means the essence and glory can be seen in the description of QS al-Baqarah(02; 225), as follows;

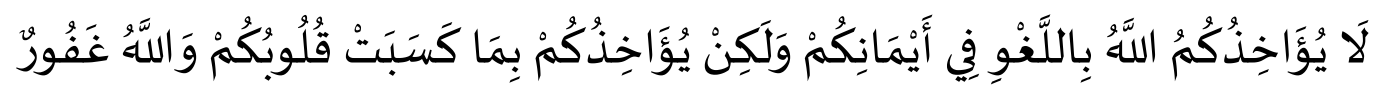

The translation;

"Allah will not call you to account for what is unintentional in your oaths, but He will call you to account for what your hearts have earned. And Allah is OftForgiving, Most Forbearing. 's

The heart, which means fluctuating, can be seen from the description of QS. alAn'am(06: 110), namely;

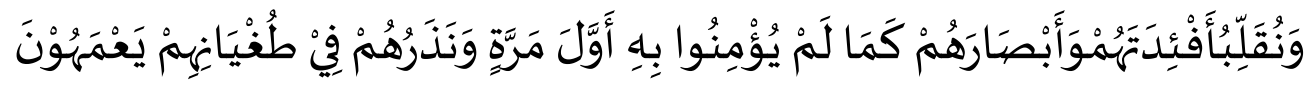

The translation;

"And We shall turn their hearts and their eyes away (from guidance), as they refused to believe therein for the first time, and We shall leave them in their trespass to wander blindly.

The verse shows that faith in the heart has no guarantee that it will be consistent. The sentence "We turned their hearts away" shows that the faith in the heart can change from believing to doubting or even unbeliever ( $k u f u r$ ).

Abu Hamid al-Gazali, al-Jurjani, Ibn Qayyim al-Jauziyyah, and Samih 'Atif alZain (a psychologist) stated in their respective works that the heart has two meanings, namely;

1. A lump of flesh that resembles an elliptical sanaubar fruit is located on the left side of the chest and is a flesh that has unique features; there are cavities inside that can pump/flow black blood and act as a source of life.

2. Something subtle (latifah), in which there are divine (rabbaniah) and psychological (ruhaniah) values that have a relationship with the

${ }^{6}$ Lihat Abū al-Husain Aḥmad bin Fāris bin Zakariyā al-Quzwinī al-Rāzìi, Mu'jam Maqāyīs alLugah, Juz V, (t.t.: Dār al-Fikr, 1399 H/1979 M), h. 17.

${ }^{7}$ See Abū al-FaḍlMuhammad bin Mukrim bin 'Ali Jamāl al-Dīn al-Anșāīì al-Ifriqīilbn Manzūur, Lisān al-'Arab, Juz I, (Cet. III; Bairūt: Dār Șādir, 1414 H), h. 685.

${ }^{8}$ Kementerian Agama RI, Al-Qur'an dan Terjemahnya, h. 36.

${ }^{9}$ Kementerian Agama RI, Al-Qur'an dan Terjemahnya, h. 141. 
physical/bodily heart (heart). The subtle heart is the essence of humanity. Therefore, a human can feel, know and recognize or understand something. Moreover, who gets the command, sanctions, reproaches, and demands. ${ }^{10}$

Meanwhile, according to al-Hakim al-Tirmizi, the heart is the abode of faith(nur al-iman), humility (nur al-khusyu'), piety(al-taqwa), love (al-mahabbah), willingness (al-rida), faith (al-yaqin), worry (al-khauf), hope (al-raja), patience (al-sabr), and awareness (al-qana'ah) ${ }^{11}$. The explanation of al-Hakim al-Tirmizi is basically in line with what has been said by Abu Hamid al-Gazali and explains matters of the heart; there is a physical and non-physical form.

The word al-qalb, when it was translated into Indonesian, was sometimes interpreted with liver and sometimes also heart. The two terms seem to overlap and sometimes present problems in explaining the difference. However, the author assesses that the two terms are the same because one of the meanings of the word al-qalb in the Mu'jam al-Wasit dictionary is an organ that functions to drain blood ${ }^{12}$, and the heart, in medical terms, is called an internal organ in the body that functions circulate blood throughout the body. ${ }^{13}$ Therefore, the word al-qalb can be termed liver and heart.

\section{B. Terminology of Heart}

Besides the word القلب, heart in Arabic language is also sometimes referred to the words الفؤاد,الصدر and اللباب.

1. The word الصدر

The word al-sadr is the masdar form of the word root sadara yasduru whose plural form is sudur. Ibn Faris explained that the word which consists of the letters and $\lrcorner$ denote two primary meanings, namely; (1) yadullu 'ala khilaf al-wird (indicating the opposite meaning of coming), namely, returning to the place where he left after leaving and (2) yadullu 'ala sadr al-insan wa gairuh (showing the meaning of the human heart and other things), namely, organs in humans and other creatures. ${ }^{14}$ Meanwhile, Ibn Manzur explains that the word sadara means something that precedes something (beginning), such as the day preceding night or summer preceding winter. ${ }^{15}$

${ }^{10}$ See Abū Hạmid Muhammad bin Muhammad al-Ṭ̂̄sì al-GazāTi, Ihyā 'Ulūm al-Dīn, Juz III, (Bairūt: Dar al-Ma'rifah, t.th.), h. 3., Take a look as well on Samị 'Ātif al-Zain, 'Ilm al-Nafs, Juz I, (Bairūt: Dār al-Kitāb al-Lubnānī, 1411 H/1991 M), h. 209., 'Ali bin Muhammad bin 'Ali al-Zain alSyarif al-Jurjānī, Al-Ta'rifăt, (Cet. I; Bairūt: Dār al-Kutub al-'Ilmiah, 1403 H/1983 M), h. 178., Ibn Qayyim Muḥammad bin Abī Bakr bin Ayyūb bin Sa'ad Syāms al-Dīn al-Jauziyah, Al-Tibyān fí Aqsām al-Qur'ān, (Bairūt: Dār al-Ma'rifah, t.th.), h. 414.

${ }^{11}$ See Abū 'Abdillah Muhammad bin 'Ali al-Hākim al-Tirmiżì, Bayān al-Farq bain al-Ṣadr wa al-Qalb wa al-Fu'ād wa al-Lubb, (Oman: Mu'assasah Äli al-Bait al-Milkiah li al-Fikr al-Islāmī, 2009 M), h. 3 . h. 753 .

${ }^{12}$ See Majma‘ al-Lugah al-'Arabiah, Al-Mu'jam al-Wasịt, Juz II, (Kairo: Dār al-Da‘wah, t.th.),

${ }^{13}$ See Nur Hidayati dan Dwi Retnowati, Kamus Lengkap Biologi, (Cet. I; t.t.: Dwimedia Press, 2010), h. 315 dan 350.

${ }^{14}$ See Ibn Fārīs, Mu ‘jam Maqāyīs al-Lugah, Juz III, h. 337.

${ }^{15}$ See Ibn Manzūr, Lisān al- 'Arab, Juz IV, h. 446. 
Thus, the word al-sadr means something that precedes or begins everything, which is one of the human body organs in the chest cavity.

\section{The word الفؤ اد}

The word al-fu'ad is a masdar form of the change in the root word fada $y a f u d u$. The sick letter (alif) in the word fada is the letter waw. Ibn Faris explained that the series of letters,,$\dot{\Theta}$, and $د$ form a word then (the meaning) can be transferred. The word الفود means most of the hair that goes through the ears; then it is said to be borrowing for the expression "two wings of an eagle" with فودان. ${ }^{16}$ Meanwhile, Ibn Manzur explained that fu'ad is the membran of the liver, while al-qalb is the seeds and galls. ${ }^{17}$ Based on al-Mu'jam al-Wasit, the word $a l-f u ' a d$ is interpreted as alqalb (liver/heart) and equates its function, namely in terms of seeing. However, the two words still have differences: something empty, there is no anxiety, sadness, or bad things in it. ${ }^{18}$ Thus, it can be understood that the word al-fu'ad means liver or heart as the word al-qalb. However, the emphasis is different in terms of circumstances: al-fu'ad is empty from a bad situation, while al-qalb can change from happy to sad or vice versa.

\section{The word لباب}

The word al-lubab is a masdar form of the change on the word root labba yalubbu. According to Ibn Faris, a word consisting of the arrangement of the letters $J$ and $ب$ with tasydid has two meanings: luzum wa sabat (certainty and firmness) and shows the meaning of khulus wa jadah (clarity and kindness). ${ }^{19}$ Meanwhile, according to Ibn Manzur, the word اللباب shows the meaning that is clean from everything. . . Thus, the word $a l-l u b a b$ can be interpreted with a heart that is clear from all forms of ugliness.

Based on these terms, al-Hakim al-Tirmizi described the layers/levels of the heart. They think that $a l$-sadr is the first layer or the defense fortress of the heart from disruption of desire, while al-qalb is the second layer located on sadr (chest) like the black part of the eye that is in white or as a living room in a house. Furthermore, $a l$ $f u^{\prime} a d^{21}$ is the third layer after al-qalb. The deepest layer or core of the heart is al-lubab, empty of all evil. Therefore, in this layer is the highest peak of human belief of the unity of $\mathrm{God} /$ tauhid. Here is a picture of the layers of the heart:

${ }^{16}$ See Ibn Fārīs, Mu ‘jam Maqāyīs al-Lugah, Juz IV, h. 458.

${ }^{17}$ See Ibn Manzūur, Lisān al- 'Arab, Juz III, h. 329.

${ }^{18}$ See Majma' al-Lugah al-‘Arabiah, Al-Mu'jam al-Wasit, Juz II, h. 670.

${ }^{19}$ See Ibn Fārīs, Mu'jam Maqāyīs al-Lugah, Juz V, h. 199.

${ }^{20}$ See Ibn Manzūur, Lisān al- 'Arab, Juz I, h. 729., lihat juga Abū Manșūr Muhammad bin Ahmad bin al-Azharì al-Hurawì, Tahżīb al-Lugah, Juz XV, (Cet. I; Bairūt: Dār Ihyā al-Turà̀̇ al-'Arabì, 2001 H), h. 243 .

${ }^{21} \mathrm{Al-Fu}$ 'àd inilah yang dilengkapi dengan al- 'aql sebagai alat untuk memahami hakikat dari sesuatu. 


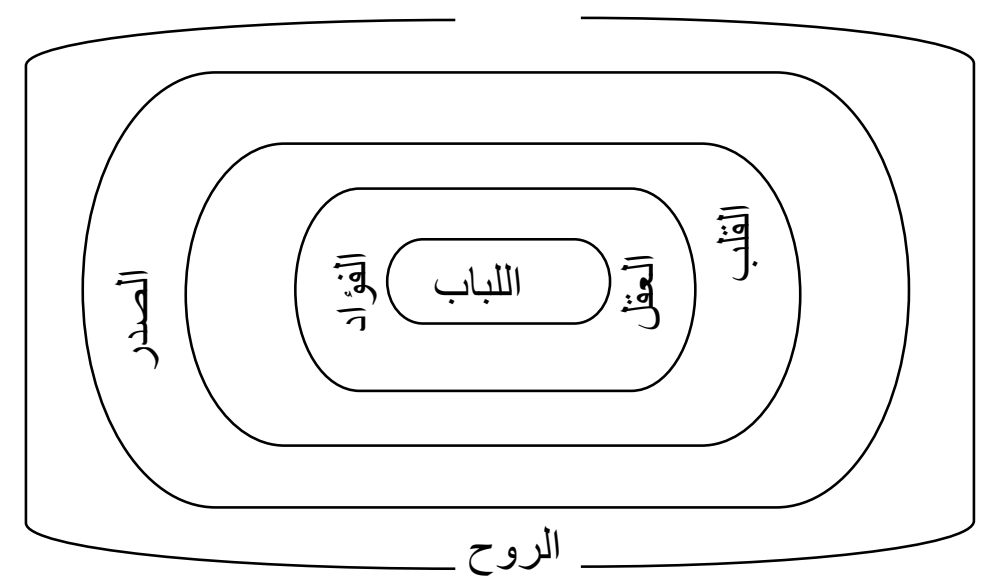

\section{The Rules of Validity of Hadith}

Considering the existence of the Prophet's hadith, only a small part which has qat'i al-wurud status (definitely its existence) and most of it is still in zanni alwurud status (estimated), then research on the quality of a hadith is still essential to ensure the truth of the narration and its legal force.

The hadith validity method that the author uses in this study is the validity method that Ibn al-Salah has formulated from the results of his study of the book of Sahih al-Bukhari and Muslims, which in Islam is considered as a holy book, the most valid after the Qur'an. ${ }^{22}$ The validity rules that Ibn al-Salah has formulated in his book are;

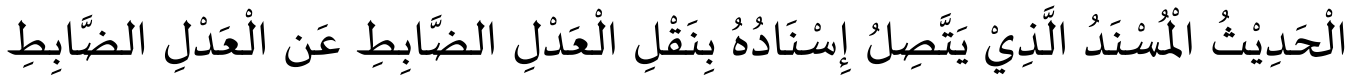 23.}

"Sahih Hadith is a hadith which is continued in the chain of hadith from the (narrators who are) fair (and) dabitfrom (narrators who are) fair and dabit (too), (until the path of) the last (sanad), and not (contains) syaz and 'illat'".

The validity method proposed by Ibn al-Salah is also used as a benchmark/requirement for the validity of the sanad and hadith by most Muslim scholars. From these methods, ittisal al-sanad (continuation of the sanad), al-'adl (the fair narrator), and dabit (the narrator has intense memorization) are used as criteria for the validity of the sanad. In contrast, they avoided contradictions and defects (meaning) as criteria for the validity of the hadith.

${ }^{22}$ SeeAbū al-Fidā'Ismā'îl bin 'Amr bin Kas̄ìr al-Qurasyī al-Bașrì, Ikhtiṣār 'Ulūm al-Hadìis, (Cet. II; Bairut: Dār Kutub al-'Ilmiyyah t.th.), h. 25.

${ }^{23}$ See Ibn al-Ṣalāh 'Uśmān bin 'Abd al-Raḥman Abū 'Amr, Ma'rifah Anwā' 'Ulūm al-Hadï̀, (Beirut: Dār al-Fikr, 1406 H/1986 M), h. 11. 


\section{RESEARCH METHODOLOGY}

The method used in collecting hadith is the takhrij method which analyzes (tahlili) the content of the hadith by using the approach of hadith science and tasawwuf science.

\section{A. The Approach of Hadith Science}

The dimension of the study in this paper is the hadith about the existence of the heart. Therefore the first step in this research will refer to the sourcebook of hadith first. Furthermore, interpreting hadith can be done using hadith science books, such as 'ilm rijal al-hadis, 'ilm al-jarh wa al-ta' $\mathrm{di}^{24} \mathrm{l}$, 'ilm $m a^{\prime} \mathrm{ani}^{25}$, and so on.

\section{B. The Approach of Tasawwuf Science}

This research seems to discuss more faith issues and how to respond to divine messages through the heart. Therefore, in this study, it is essential to use the Sufism approach to enrich the explanation of existence.

\section{RESULT OF THE RESEARCH}

\section{A. Takhrij al-Hadiths}

The hadith that the author discusses in this article is a hadith that contains information about halal and haram laws issues that have clear boundaries, but between the two, some things are vague (syubhat). At the end of the hadith, the heart's existence is a determinant of the good or bad condition of the body. The hadith is shown as follows;

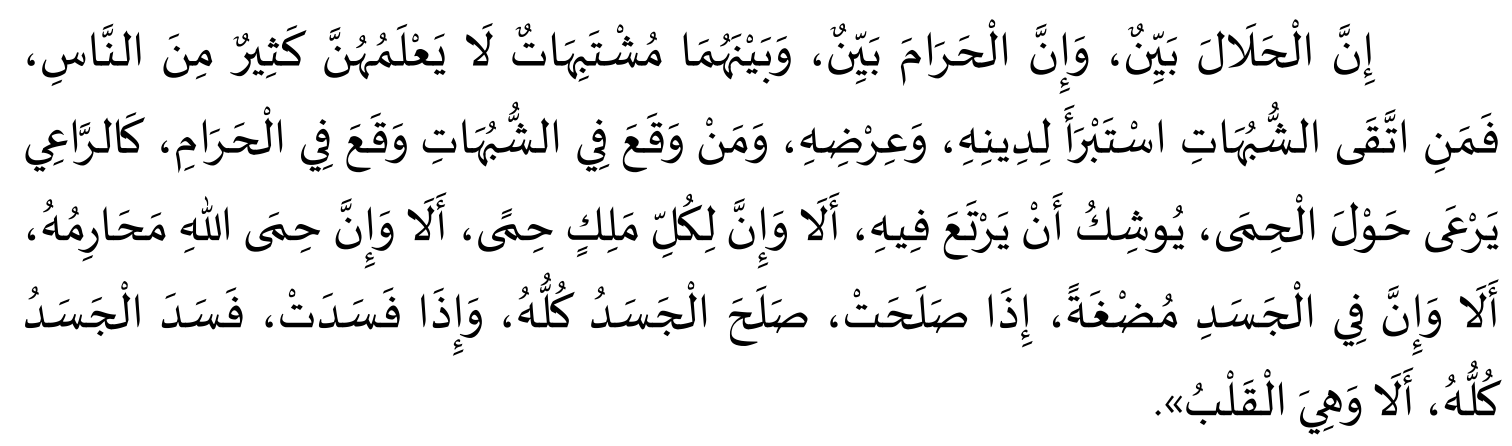

It means:

"Verily, what is halal has become apparent (transparent), and what is haram has become apparent. Moreover, between the two, there is a dark matter, which most people do not know, so whoever keeps himself from doing doubtful things, then his religion and honor will be saved, but whoever falls into doubtful matters

${ }^{24}$ The science that discusses about the narrators in terms of whether their history is accepted or rejected. See, Abd' al-Karìm al-Khațīb, Ușūl al-Hadis̀: 'Ulūmuh wa Muṣtalahuh (Bairūt: Dār al-Fikr, 1975 M), h. 266. Lihat, A. Syahraeni, Kritik Sanad dalam Perspektif Sejarah (Cet. I; Makassar: Alauddin Press, 2011 M), h. 99.

${ }^{25}$ The science that studies Arabic words, according to the circumstances, so that there are differences of opinion about a sentence due to different circumstances. Arifuddin Ahmad, Metodologi Pemahaman Hadis Kajian Ilmu Ma'ānì al-Hadis, h. 5. 
then falls into the forbidden. It is like a shepherd who grazes on the edge of the yard, fearing that his cattle will enter it. Know that every king has a prohibition, and the prohibition of Allah is something that is forbidden. Know that there is a lump of flesh in every human body; if that is good, then the whole body is good, but if that lump of flesh is damaged, then the whole body is corrupted. You know, the blood clot in the heart."

Narratively, the hadith has 16 lines (sanad) which are spreaded in the source book of 9 imam (al-kutub al-tis'ah), namely; 2 narrations on the book of Sahih alBukhari, 1 history on the book of Sahih Muslim, 2 narrations on the book of Sunan Abi Daud, 1 history on the book of Sunan al-Turmuzi, 2 narrations in the book of Sunan alNasa'i, 1 history in the book of Sunan Ibn Majah, 1 history in the book of Sunan alDarimi and 6 narrations in the book of Musnad Ahmad bin Hanbal. The extant (matan) hadiths are;

1. The History in the Book of Sahih al-Bukhari

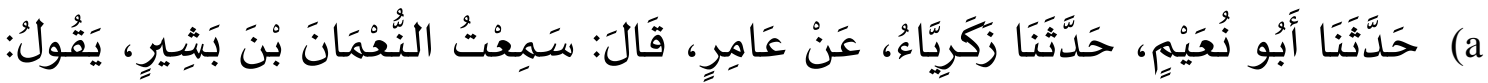

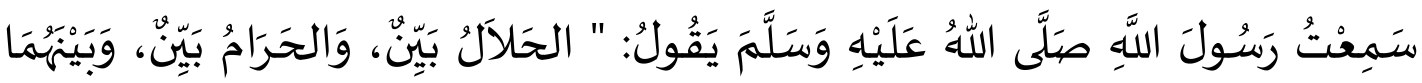

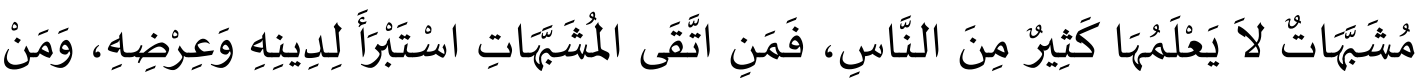

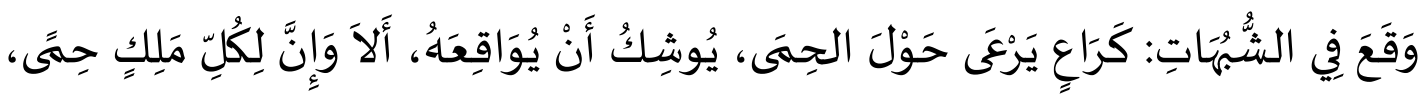

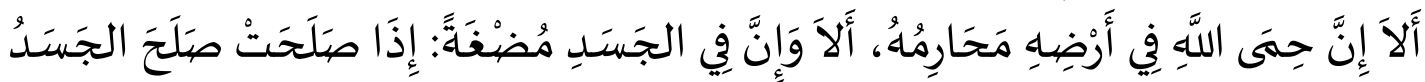

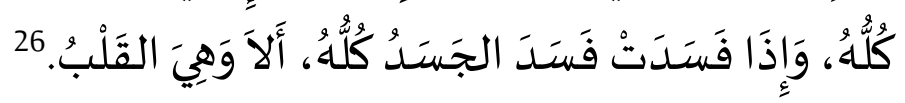

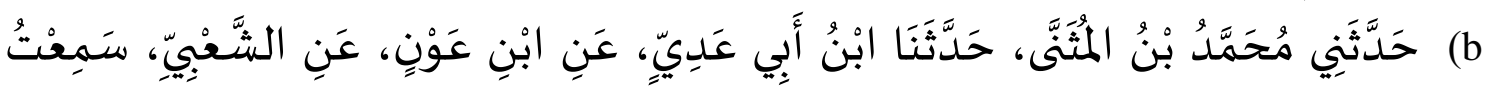

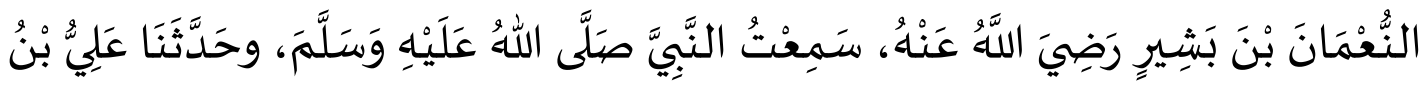

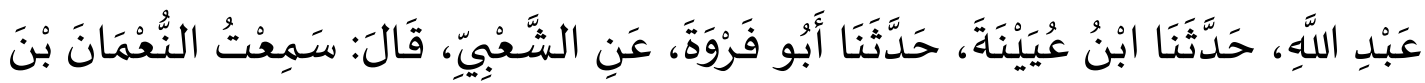

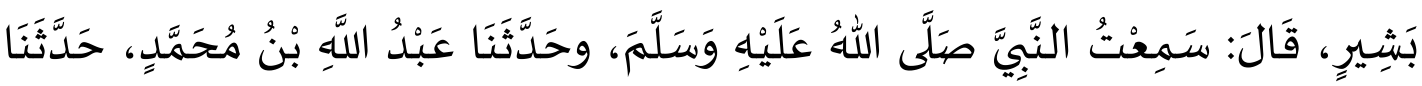

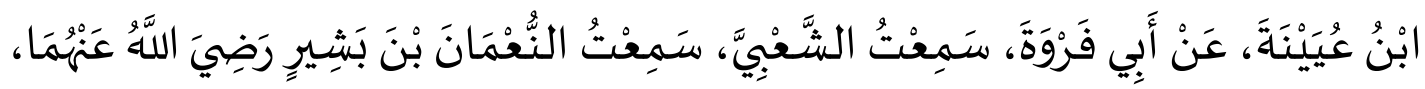

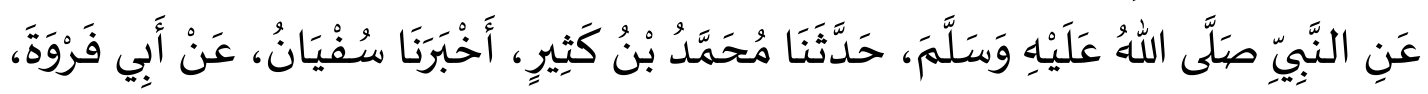

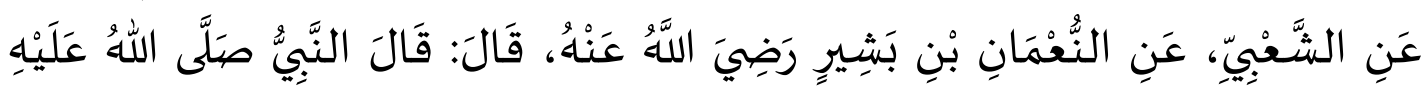

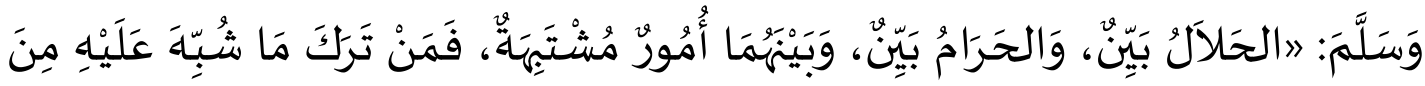

${ }^{26} \mathrm{Abū}$ 'Abdillah Muhammad bin Ismā‘cll bin Mugīrah al-Bukhārī, Al-Jāmi 'al-Ṣahịh al-Musnad min Hadiss Rasūlillah $S A W$ wa Sunanu-hu wa Ayyāmu-hu, Juz I, (Cet. I; Kairo: al-Matba'ah alSalafiyyah, 1400 H), h. 34. 


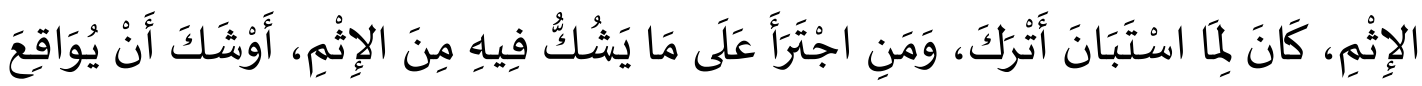

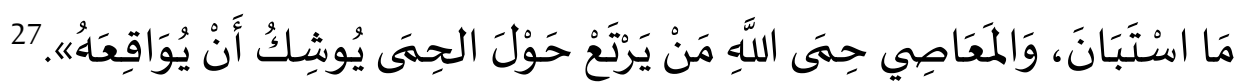

2. The History in the book Sahih Muslim

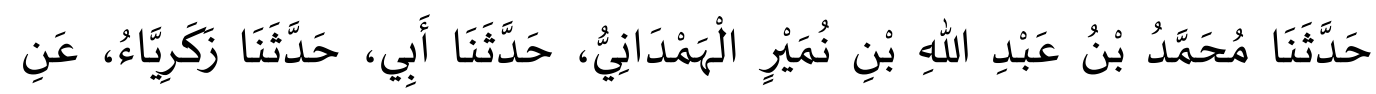

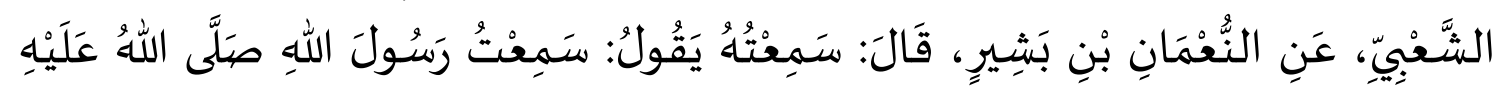

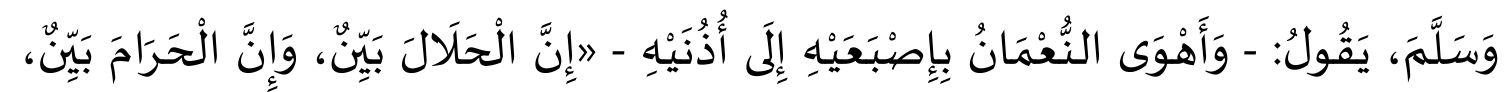

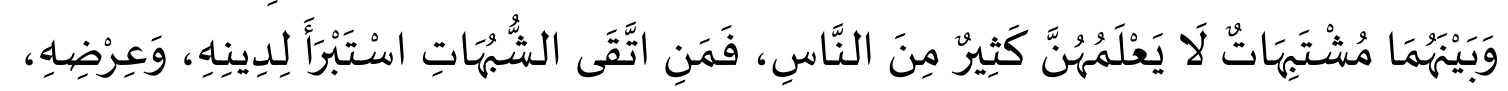

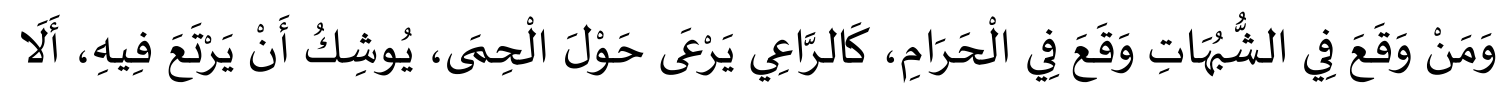

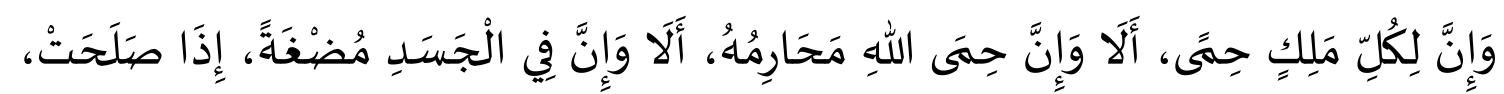

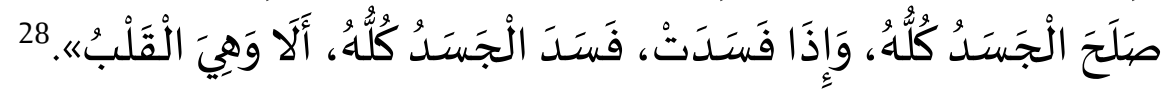

3. The History in the book of Sunan Abu Dawud

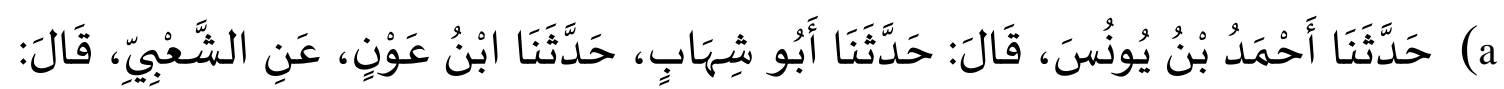

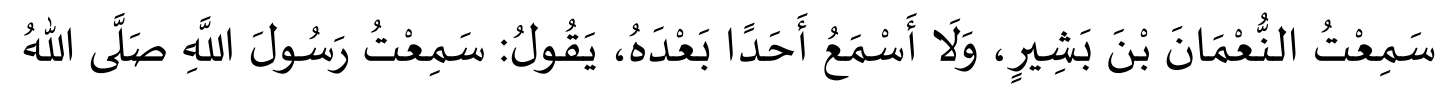

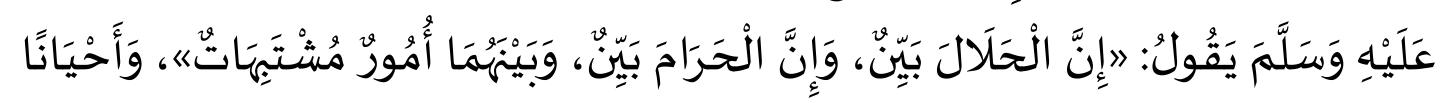

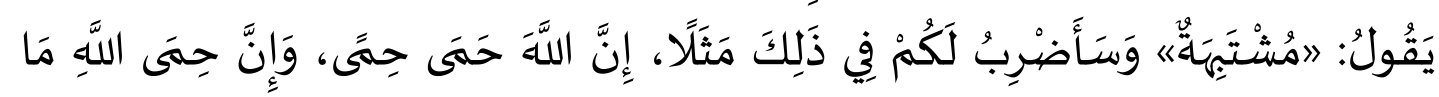

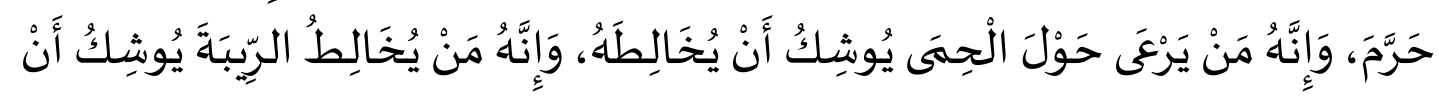

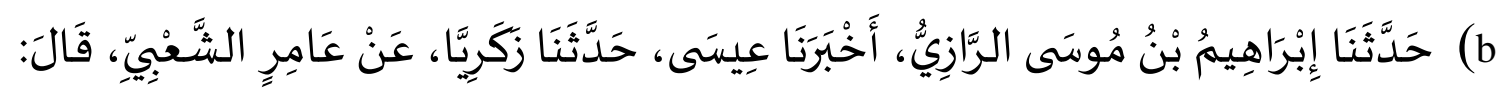

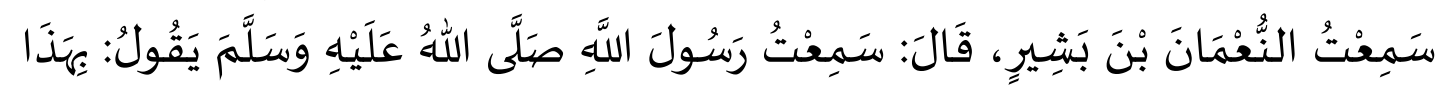

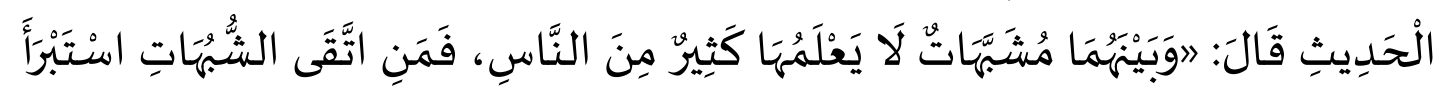

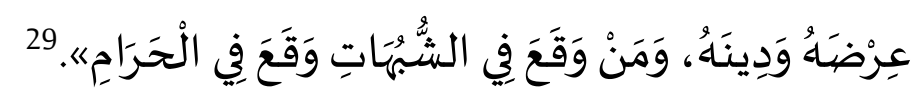

${ }^{27}$ Al-Bukhāri, Al-Jāmi 'al-Ṣahịḥ̣ al-Musnad..., Juz II, h. 74.

${ }^{28} \mathrm{Abu}$ al-Ḥusain Muslim bin al-Ḥajjāj bin al-Qusyairī al-Naisabūri, Al-Musnad al-Sahịh alMukhtasar bi Naql al-'Adl 'an al-'Adl ilā Rasūlillah SAW, Juz III, (Bairut: Dār Ihyā al-Turās al-'Arabì, t.th), h. 1219.

${ }^{29}$ Abū Dāwūd,Sulaimān bin al-'Asy'as bin Isḥāq bin Basyīr bin Syidād bin 'Amr al-Azadi alSijistāni, Sunan Abī Dāwūd, Juz III, (Cet. I; Bairut: Dār Ibn Ḥazm, 1418 H/1998 M), h. 405. 
4. The History in the book of Sunan al-Turmuzi

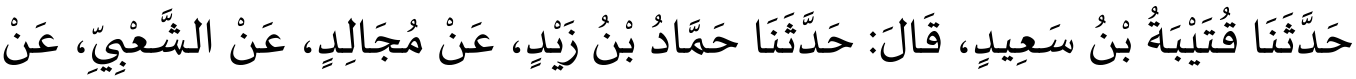

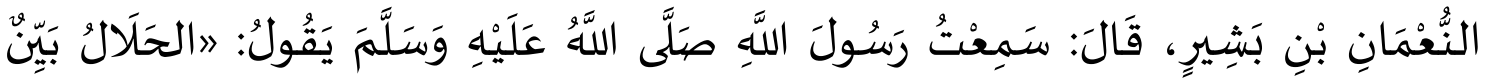

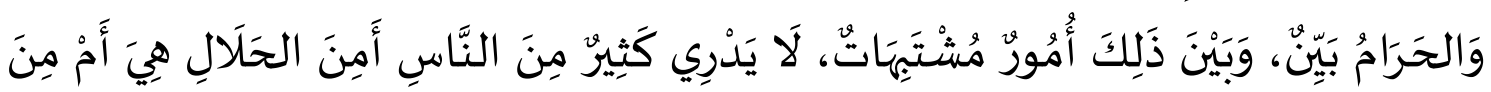

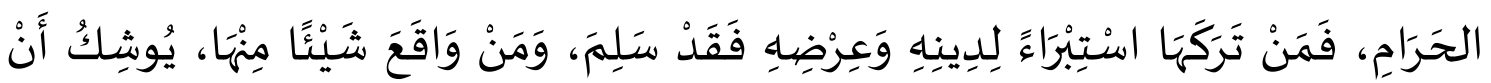

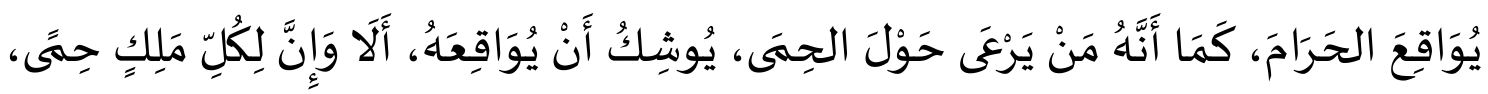

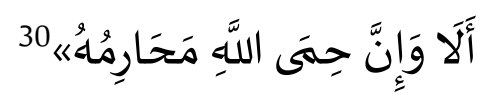

5. The History in the book of Sunan al-Nasa' $i$

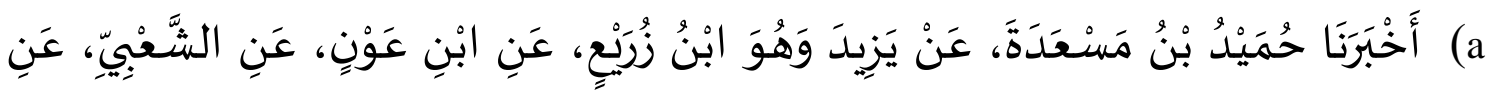

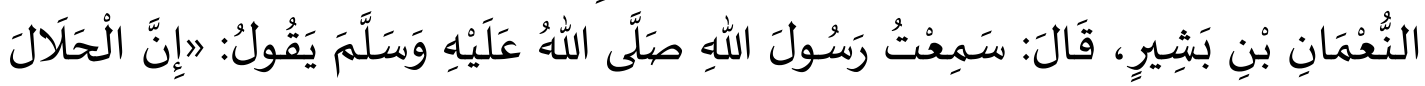

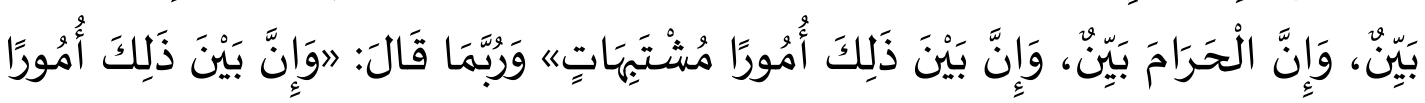

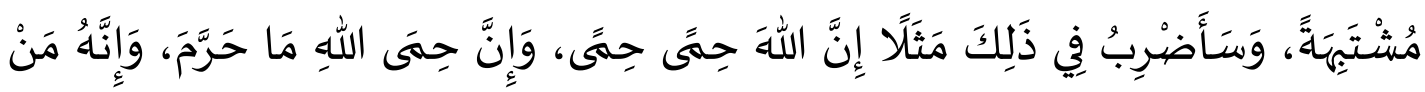

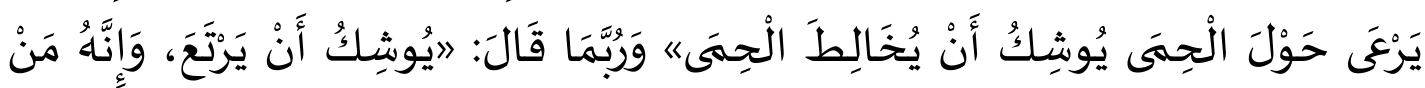

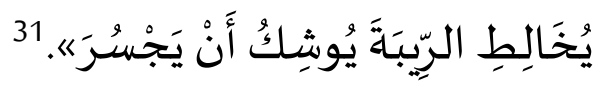

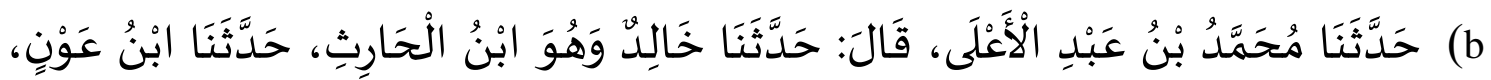

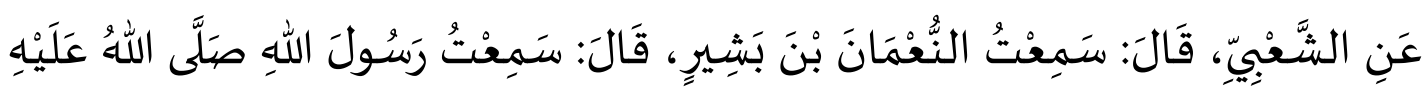

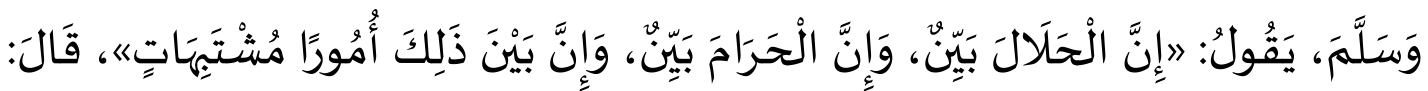

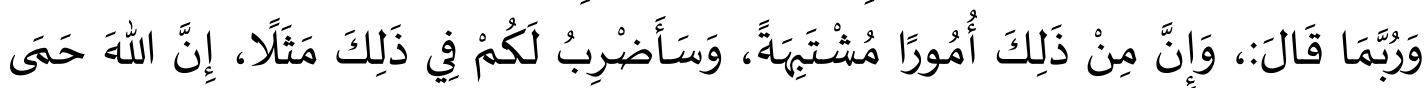

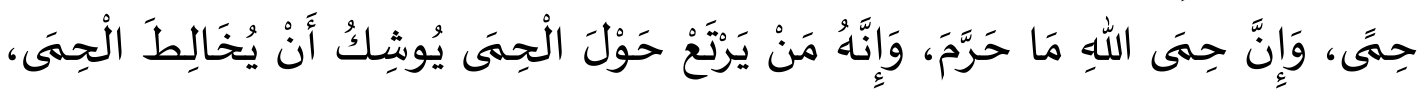

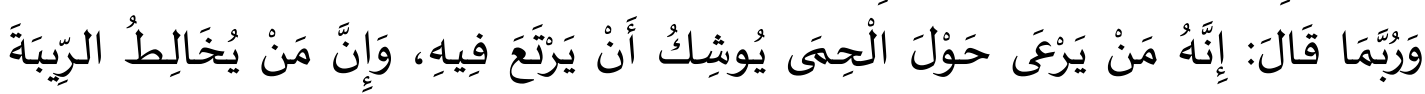

${ }^{30} \mathrm{Abū}$ 'Isā Muhammad bin 'Isāa bin Saurah al-Turmużī, Al-Jāmi' al-Ṣahịhh, Juz III, (Cet. II; Mesir: Syarikah Maktabah, 1388 H/1968 M), h. 503.

${ }^{31} \mathrm{Abū}$ 'Abd al-Raḥmān Aḥmad bin Syu'aib bin 'Alì al-Khurāsānial-Nasā'ì, Al-Sunan al-Kubrā li al-Nasāi, Juz V, (Cet. I; Bairut: Mu’assasah al-Risālah. 1421 H/2001 M), h. 117.

${ }^{32}$ Al-Nasā'ì, Al-Sunan al-Kubrā li al-Nasāi, Juz VI, h. 5. 
6. The History in the book of Sunan Ibn Majah

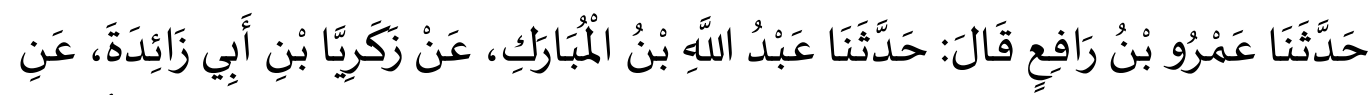

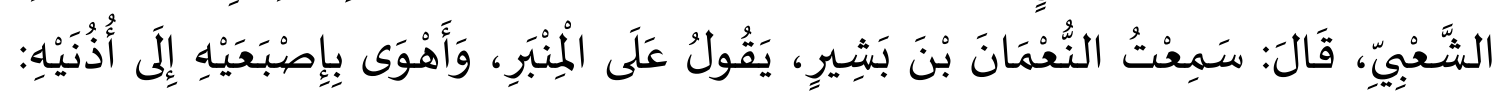

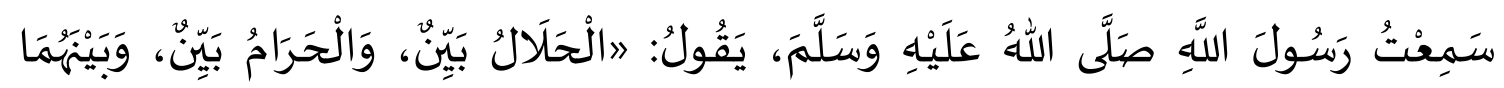

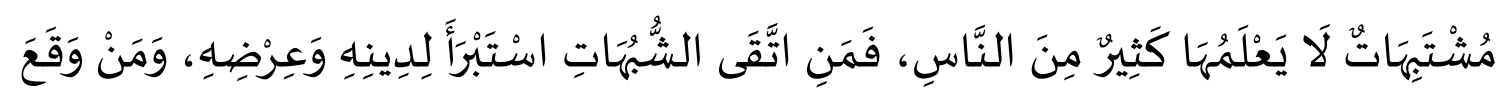

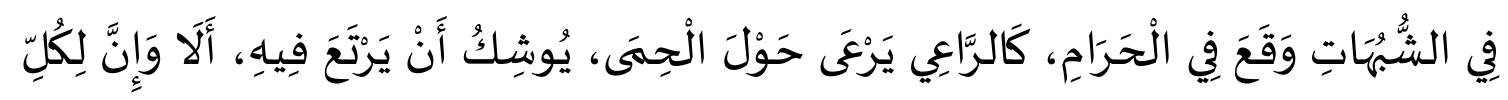

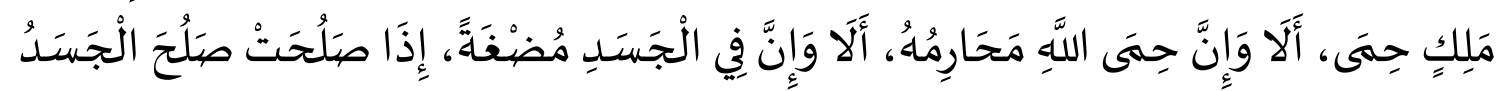

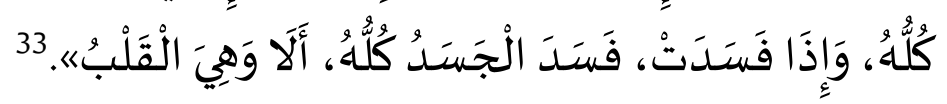

7. The History in the book of Sunan al-Darimi

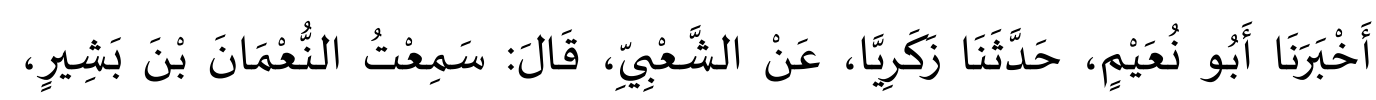

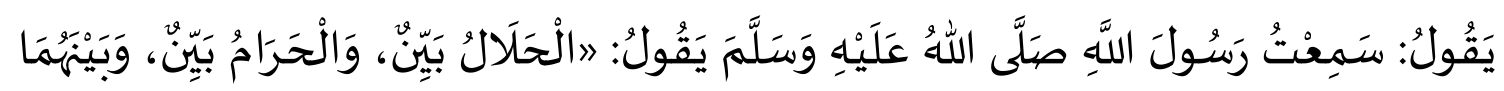

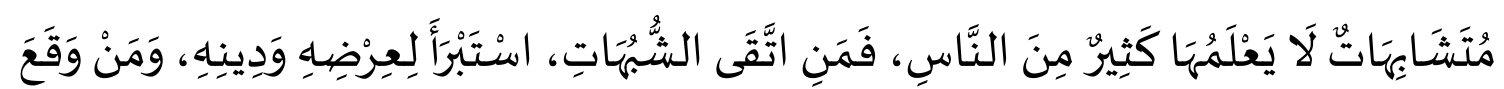

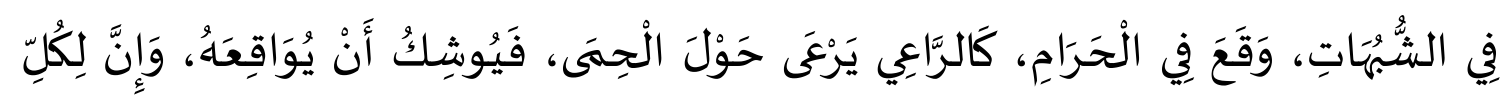

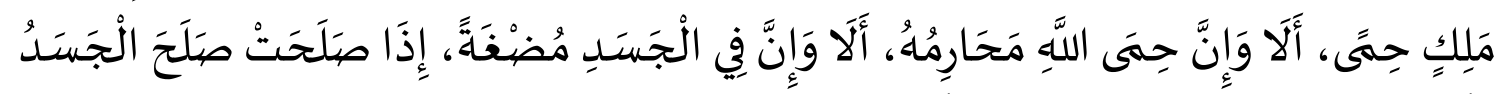

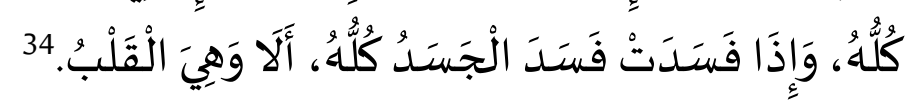

8. In the Book of Sunan Ahmad bin Hanbal

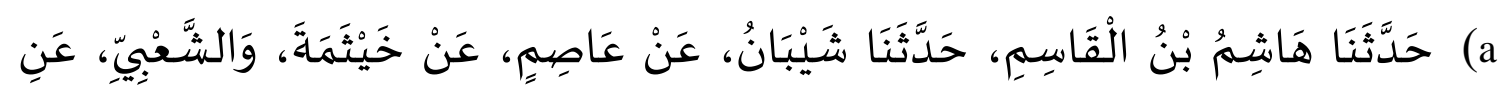

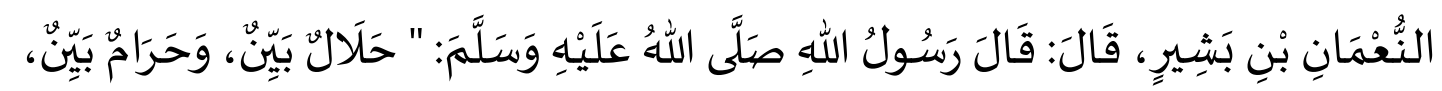

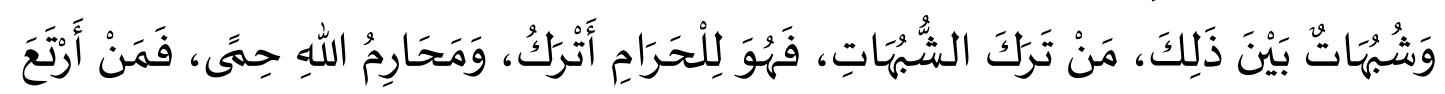

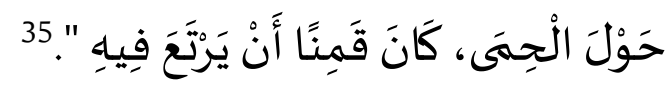

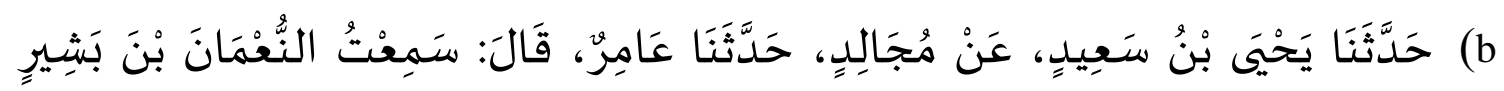

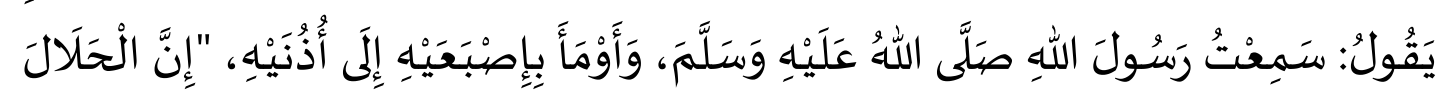

${ }^{33} I b n$ Mājah,Abū 'Abdillah Muhammad bin Yazīd al-Qazawainī, Sunan Ibn Mājah, (Cet. I; Riyāụ: Maktabah al-Ma‘ārif li al-Nasyr wa al-Tawzī‘, 1418 H), h. 658.

${ }^{34} \mathrm{Abu}$ Muhammad 'Abdullah bin 'Abd al-Raḥman bin al-Faḍl bin Bahrām bin 'Abd al-Ṣamad al-Tamīmi al-Samaraqandial-Dārimī, Sunan al-Dārimì, Juz III, (Cet. I; Saudi Arabiyyah: Dār al-Mugni li al-Nasyr wa al-Tawzi', 1412 H/2000 M), h.1647.

${ }^{35} \mathrm{Abu}$ 'Abdillah,A ḥmad bin Muḥammad bin Hanbal bin Hilāl bin Asad al-Syaibānī, Al-Musnad li Imām Aḥmad bin Hanbal, Juz XV, (Ceț I; Kairo: Dār al-Ḥadis, 1416 H/1995 M), h. 146. 


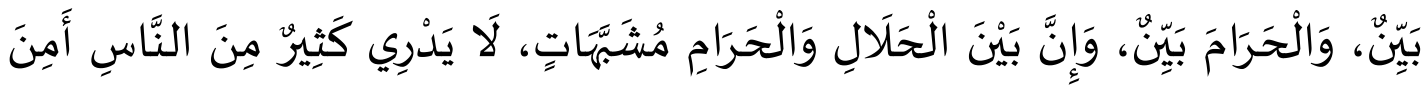

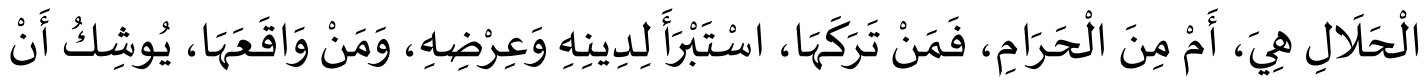

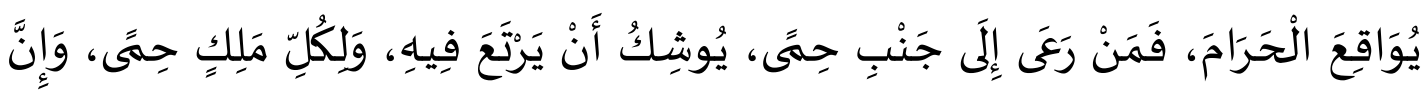
حِنَى اللهِهِ مَحَارِمُهُ ".

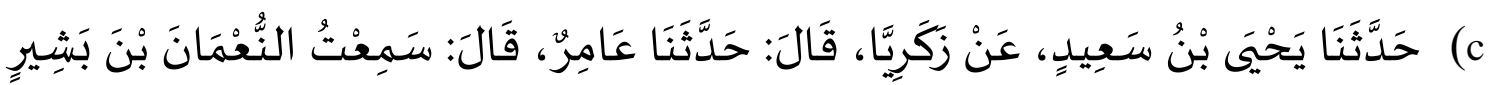

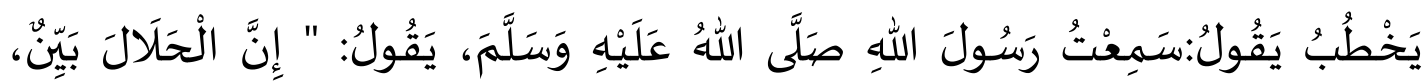

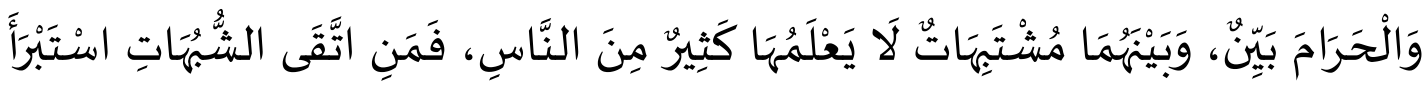

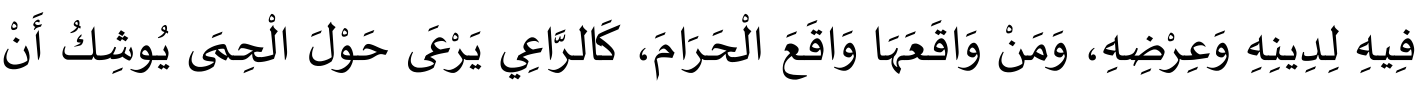

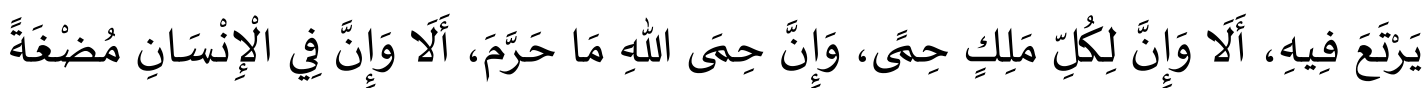

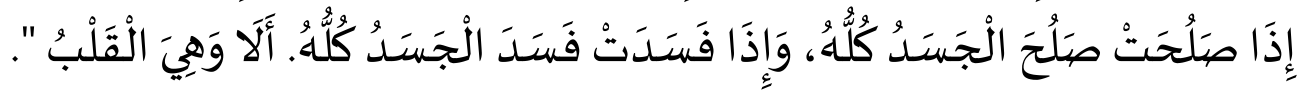

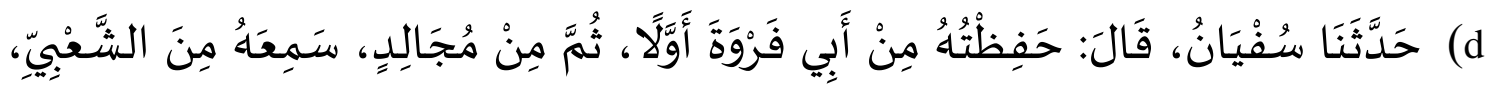

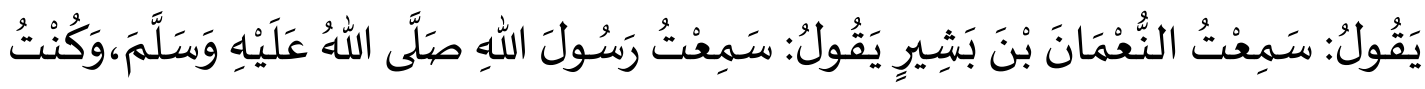

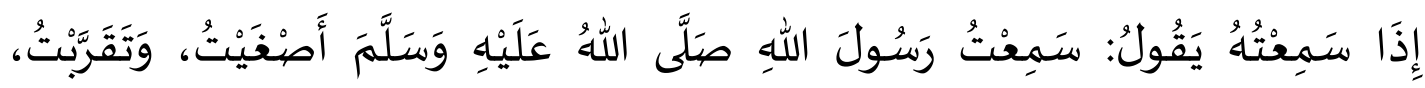

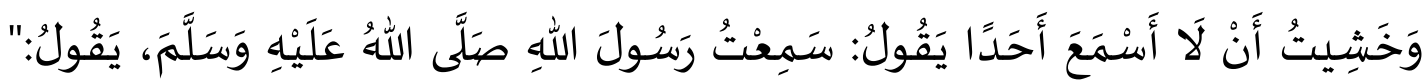

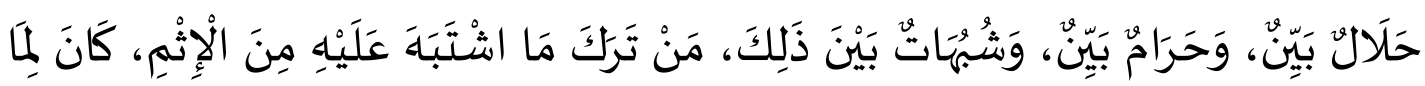

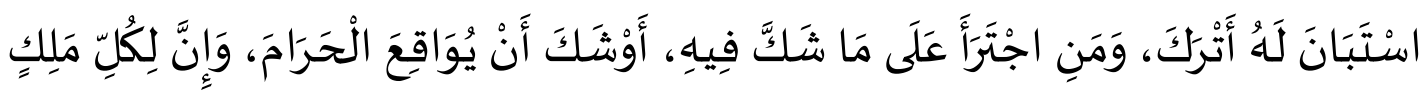

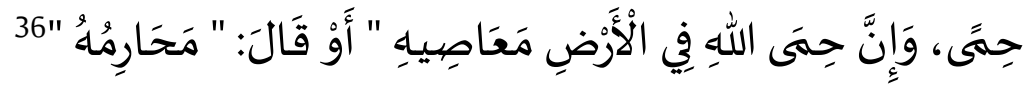

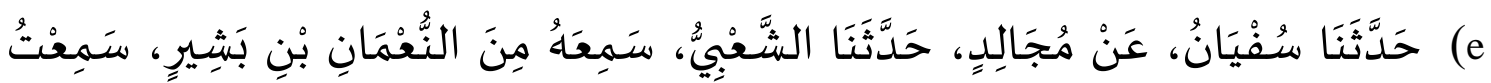

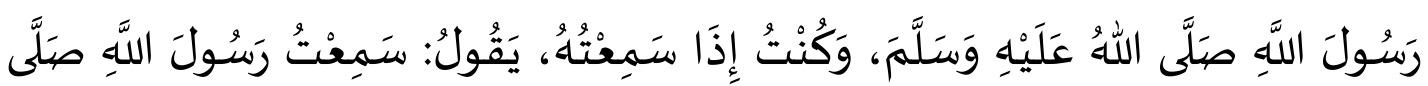

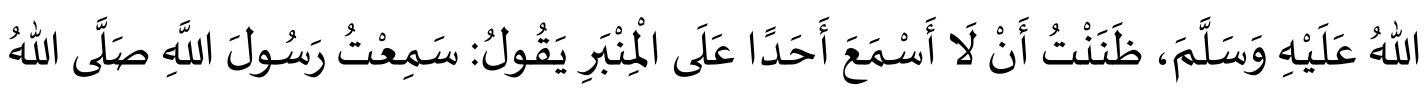

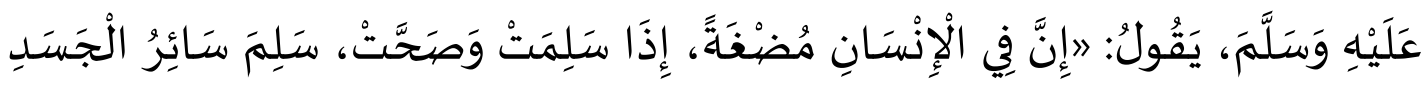

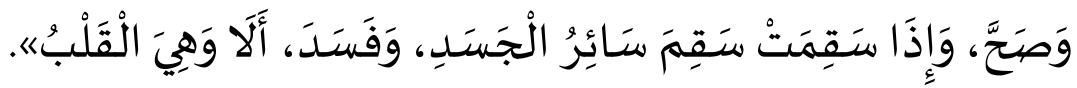

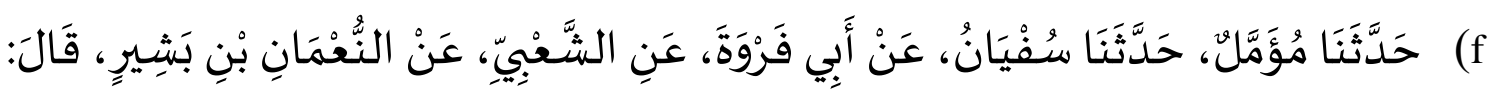

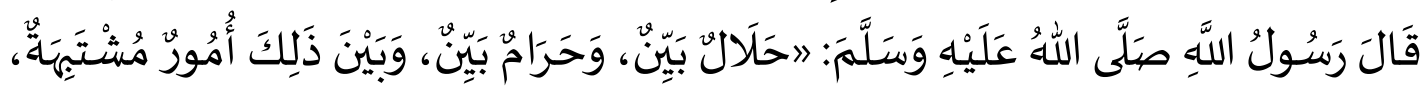

${ }^{36}$ Aḥmad bin Hanbal, Al-Musnad, Juz XIV, h. 152, 154 dan 157. 


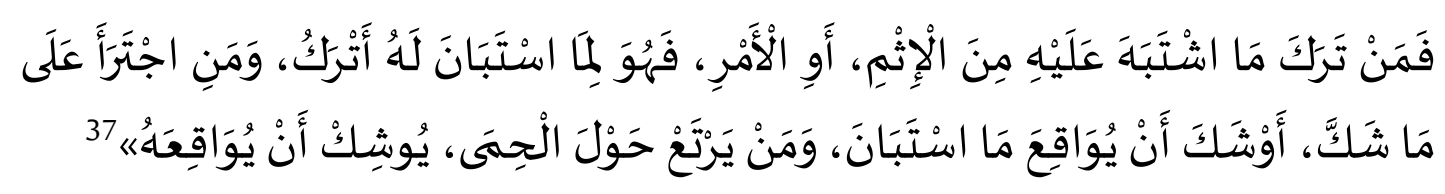

These narrations were only quoted from one friend, al-Nu'man bin Basyir who showed that the hadith did not have syahid. Likewise, from the tabi'in, only one person received the hadith from al-Nu'man bin Basyir, namely 'Amir al-Syu'bi, therefore he is the only mutabi' of the hadith. The history seems to be circulating in Iraq because alNu'man bin Basyir and al-Syu'bi came from the city of Kufah, while 5 of his students lived in the cities of Baghdad, Basrah, and Kufah.

\section{B. The Quality of Hadith}

\section{The Quality of Sanad}

Regarding the research on the hadith chain/sanad, the researcher considers that there is no need to criticize the sanad, because of the involvement of Imam al-Bukhari and Muslims in the transmission of hadith where the majority of hadith Muslim scholars have undoubted capacity. Moreover, the respective books of the two have been considered as the most authentic books after the Qur'an. In fact, in applicative terms, Muslim scholars refer to the rules of hadith validity that Ibn al-Salah has formulated based on what they both practice in selecting hadith. Therefore, even if there is a poor quality of the hadith sanad of (da'if) automatically, it will be elevated to hasan li gairih as formulated by Imam al-Turmuzi as long as there are no problems in the matan.

\section{The Quality of Matan}

There are pronunciation differences between the beginning of the matan or between the phrases of the sentence. Therefore, it is necessary to determine the original pronunciation that (possibly) came from the Prophet to be able to make comparisons between the matan of hadith to find illah and syaz on the other matan. In addition, the determination of the original pronunciation aims to understand the hadith that is in line with the initial context of its delivery.

Based on observations of various variations of pronunciation, the author strongly thinks that the original pronunciation that the Prophet conveyed among these narrations was the history contained in the book of Sunan Ibn Majah from 'Amru bin Nafi' from 'Abdullah bin al-Mubarak from Zakariya bin Za'idah because the sentence الحلال بين is the most widely used as the beginning of the hadith. In addition, its pronunciation has many similarities with the matan pronunciations of other narrations. Moreover, in particular, the narration of Ibn Majah that most mention the process of conveying the hadith from al-Nu'man bin Basyir as the only friend who heard the hadith from the Messenger of Allah, then he conveyed the hadith in the sermon and was heard by 'Amir al-Syu'bi until it reached Zakariya bin Za'idah, Abu Furwah, 'Abdullah bin 'Aun, 'Asim and Majallid. The pronunciations are;

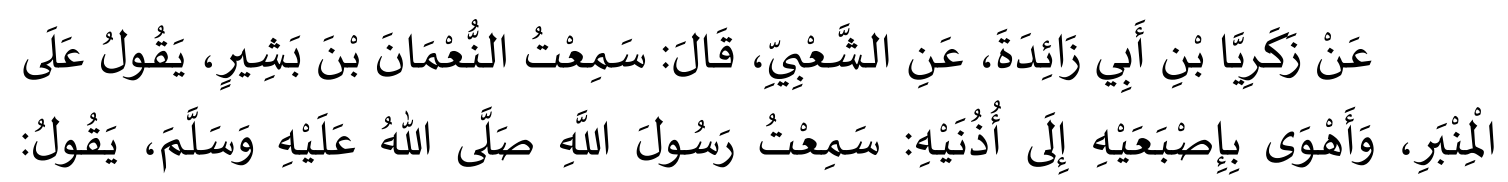

\footnotetext{
${ }^{37}$ Aḥmad bin Hanbal, Al-Musnad, Juz XIV, h. 165 dan 168.
} 


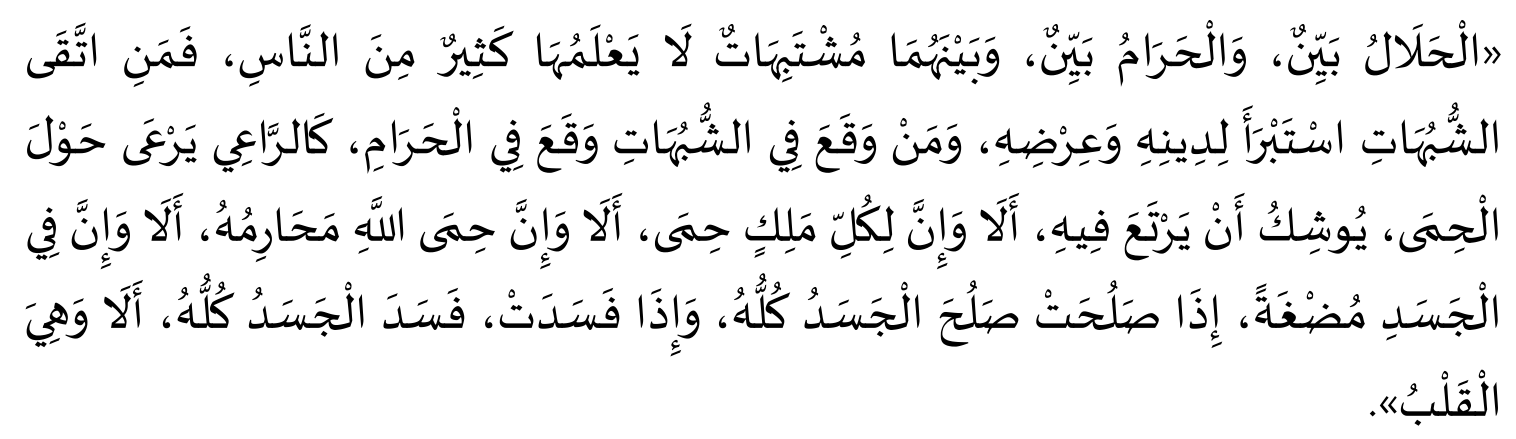

It means:

"From Zakariya bin Abu Za"idah from al-Sha'bi, he said; I heard al-Nu'man bin Basyir says; above the pulpit and hinted with his fingers in his ears, "I heard the Prophet said: "(Something) that is halal is clear and what is haram is also clear, and between them, there are doubtful (vague) matters that are most people do not know it. Whoever can protect himself from doubtful matters means that he has protected his religion and honor, and whoever falls into doubtful matters means that he has fallen into something haram. Like a herdsman who herds his livestock around a forbidden area, it is feared that his animal will enter the forbidden area. Know that every king has a prohibition, and the prohibition of Allah is something that is forbidden. There is a blood clot; if it is good, then the whole body will be good. However, if it is damaged, then the whole body will be damaged; know that the clot of blood is the heart."

After determining the original pronunciation of the 16 hadiths matan, the author conducted a study of all the hadiths to find out whether the hadiths avoided from 'illah or not by using minor rules to avoid 'illah, which included addition (ziadah), subtraction (nuqsan), insertion (idraj), reversal (inqilab) change (tagyir), changes in shakal/letters (tashif/tahrif) and mixing with other hadiths (idtrab). These things can make a hadith be illah if it destroys the meaning of the substance of hadith. After that, the writer will continue research on the aspect of syaz by using the minor method, contrary to the Qur'an, authentic hadith, historical facts, and logic. ${ }^{38}$

a) Free from illah

Based on the author's observations on the hadiths regarding the existence of the heart, it appears that there are changes, subtractions, additions, insertions, and editorial twists in various related subjects. However, these things do not damage the meaning of the substance of the hadith. Therefore, all narrations relating to the existence of the heart are free from illah and can be concluded as narrated by secar makan (riwayah bi almakna).

b) Free from syaz

The results of this study indicate that the hadith about the existence of the heart is protected from syaz (contradictory) both with the Qur'an, authentic hadith, historical

${ }^{38}$ See Arifuddin Ahmad, Paradigma Baru Memahami Hadis Nabi, (Cet. I: Jakarta: Renaisan, 2005 M.), h. 117. Bandingkan dengan Kamaruddin Amin, Menguji Kembali Keakuratan Metode Kritik Hadis, (Cet. I; Jakarta: Hikmah, 2009), h. 58. 
facts, or logic; it is in line. Thus, the heart existence hadith can be concluded to be of good quality, sanad, and matan, which can be used as evidence.

\section{The Content of the Hadith about the Existence of Heart}

According to Ibn Daqiq, the al-mudgah pronunciation in the hadith about the heart means a lump of meat like the size of food that can be chewed in the mouth, indicating that the heart's size is tiny, but the effect is substantial. The lump of flesh is named al-qalb (heart), which is the noblest organ among other body organs because of the dexterity of the ideas in it and the doubts that exist. ${ }^{39}$ This explanation is certainly in line with al-Gazali's explanation which describes the physical shape of the heart with an elliptical sanaubar fruit.

ألآ وإنّ في الجسد مضغة ..الخ Al-Sallami in his commentary on the hadith fragment that it contains good signs of body movements, rejection of things that are forbidden and caution against things that are not clear judged by virtue condition of the human heart. If his heart is healthy (good), that is, his love is only for Allah and what Allah loves, and he fears only Allah and is afraid of falling into what Allah hates, then all the movements of his limbs will lead to good things, arising denial to things that Allah has forbidden and always be aware of things that are not clear to keep himself from falling into things that are forbidden. On the other hand, if the heart is damaged, it means that it has been controlled by lust and demands what it likes even though Allah hates it so that all movements of its limbs are damaged, leading to all immoral acts and doing things that are not clear because it follows the pleasures of the heart (lust). ${ }^{40}$ Meanwhile, according to Imam al-Nawawi in his Sahih Muslim sharia book, "a good condition of the heart will affect the condition of the body, while a bad condition of the heart will affect the condition of the body. ${ }^{41}$

Based on the information above, it can be understood that the heart is physically a lump of flesh and is the center of the movement for all the body organs. The good or bad actions of each body organ depend on the heart's good or bad quality. Therefore, the formative of heart existence has a significant influence on the good or bad condition of all body members, which is related to health. While normatively, the good or bad of the heart affects the good or bad of the actions carried out by all other body members, which are related to actions under religious teachings or violating them.

The existence of the heart as a determinant of the good or bad of every action of the human body shows the heart's position as the person in charge of all the actions of all the members of the human actions, like the hadith of the Prophet, which came from the companions of Abu Hurairah, as follows;

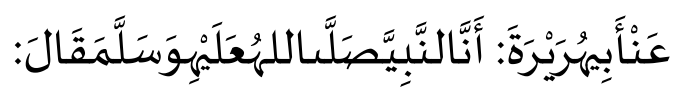

${ }^{39}$ See Ibn Daqiiq Taqī al-Dīn Abū al-Fath Muhammad bin 'Ali bin Wahb bin Muṭi' al-Qusyairi, Syarh al-Arba'in al-Nawawiyah fí al-Hadis al-Ṣahịhah al-Nabawiyah, (Cet. VI; t.t.: Mu'assasah alRayyān, 1424 H/2003 M), h. 48.

${ }^{40}$ See Zain al-Dīn 'Abd al-Raḥman bin Ahmad bin Rajab bin al-Ḥasan al-Sallāmī, Jāmi' al'Ulūm wa al-Hukm fị Syarh Khamsìn Hadișan min Jawāmi' al-Kalim, Juz I, (Cet. VII; Bairūt: mu'assasah al-Risālah, 1422 H/2001 M), h. 210.

${ }^{41}$ See Abū Zakariyā Maḥyī al-Dīn Yaḥyā bin Syarf al-Nawawī, Al-Minhāj Syarh Ṣaḥịh Muslim, JuzXI, (Cet. II; Bairūt: Dār Ihyā al-Turās̀ al-`Arabī, 1329), h. 27. 


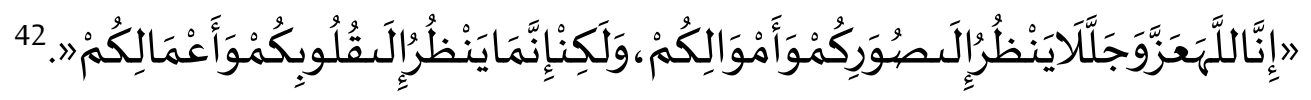

It means:

"From Abu Hurairah, he said; The Prophet said: "Verily Allah 'Azza wa Jalla does not see your body shape and wealth, but He looks at your heart and your deeds." (H.R. Ahmad)."

The above hadith is a warning to humans that assessing the good or bad quality of the human being is not judged by physical form (beauty/good looks, big or small body posture) and not on wealth. However, what is judged is excellent or lousy heart and actions. In his explanation, al-Sallami said that most people sometimes have a good image because of their wealth, honor, and position in the world, but their hearts are damaged in terms of piety. While some people do not have these things, their hearts are full of piety. Therefore, they become the most honorable person in the sight of Allah. ${ }^{43}$ Al-Hurawi al-Qari added that heart is the place of belief, honesty, sincerity, riya', popularity, and all good or bad character/character resides. In contrast, the meaning of the word و و أعمالكم goodness and badness radiates in the form of attitudes or actions from it. 44

The explanations of al-Sallami and al-Hurawi above are essentially under the information in QS al-Hujurat (49:13), which confirms that the noblest of people in the sight of Allah is the most pious. Thus, the true glory for humans depends on the quality of the heart because the heart is an organ that will lead to good or bad. Therefore, it is very logical if the heart is the center of Allah's attention in assessing every human movement because piety, belief, faith, sincerity, honesty, intentions, and morals reside. This heart is what al-Gazali calls qalb al-latifah (smooth heart), which the five senses cannot touch, but who receives orders, sanctions, reproaches, and demands from Allah.

The heart issues can be likened to a kingdom, where the heart acts as a king with subordinates or soldiers. When the king is good, the soldiers will also do good, and if the king is wrong, the soldiers will also do wrong because basically, the soldiers will not do anything except what the king commanded.

Allah, as the creator, puts the organ (heart) in every type of animal (including humans), which is equipped with a support system to obtain its needs (lust). Therefore, it will be found in every type of animal that can obtain its needs and distinguish between harmful and beneficial things and that lump of flesh (heart). However, as confirmed, Allah put the mind in the human heart as a specialty and a differentiator with animals ${ }^{45}$ in QS al-Hajj(22:46), as follows;

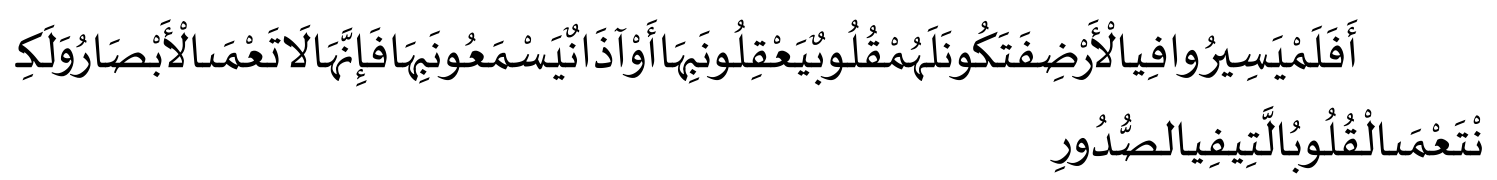

${ }^{42} \mathrm{Abū}$ 'Abdillah Aḥmad bin Hanbal, Al-Musnad li Imām Aḥmad bin Hanbal, Juz VII, (Cet I; Kairo: Dār al-Ḥadìs, 1416 H/1995 M), h. 495.

${ }^{43}$ See Zain al-Dīn al-Sallāmī, Jāmi ' al- 'Ulūm wa al-Hukm...,Juz I, h. 992.

${ }^{44}$ See Abū al-Ḥasan 'Ali bin Muhammad Nūr al-Dīn al-Malā al-Hurawīi al-Qāri, Marqāh alMafātị̣ Syarḥ Misykāh al-Mașābịh, Juz VIII, (Cet. I; Bairūt: Dār al-Fikr, 1422 H/2002 M), h. 3331.

${ }^{45}$ See Ibn Daqiq al-Qusyairi, Syarh al-Arba īn al-Nawawiyah..., h. 48. 
The translation:

"Have they not traveled through the land, and have they hearts wherewith to understand and ears wherewith to hear? Verily, it is not the eyes that grow blind but the hearts in the breasts that grow blind." 46

According to al-Mawardi, al-Sam'ani and Fakhr al-Din al-Razi, deduction of the verse فتكون لهم قلوب يعقلون بها show two things, namely; the mind is the source of knowledge and is located in the heart. Fakhr al-Din al-Razi stated that the passage of the verse shows the heart's function as a tool for understanding. Thus, the explanation above shows that the mind has a function to understand ${ }^{47}$ something in the heart, strengthened on QS. Al-A'raf (07:179), as follows;

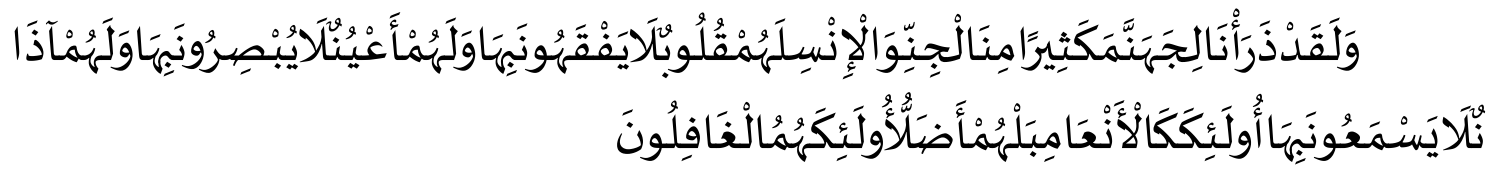

The translation:

"And indeed, We have created many of the jinn and humankind for Hell. They have hearts wherewith they understand not; they have eyes wherewith they see not, and they have ears wherewith they hear not (the truth). They are like cattle, nay even more astray: those! They are the heedless ones. "48

The verses above are closely related to Ibn Daqiq's explanation of the specificity of the reason that Allah has placed in the human heart as a distinction between the human heart and the animal heart, namely animals act based on desires (lust), while humans (should) act based on their minds. When humans do not use reason in doing something, they are referred to as misguided people, even more astray than animals who are not given reason to know between right or wrong and valuable or not.

Regarding the location of the mind, there is a contradictive opinion among Muslim scholars. Some of them think that the brain is the mind location, which in the Arabic language is called al-dimag. This opinion is believed by Abu Hanifah and doctor (tabib) because when the brain is damaged, the mind automatically will be damaged as well. ${ }^{49}$ According to most Muslim scholars, the mind is located in the heart (not in the brain); that view is believed by the scholars from the shafi'iah, mutakallimin (tasawwuf), and philosophy circles.

Briefly, it can be understood that the brain has the function of managing, maintaining, and distributing information. The mind has the primary function of

${ }^{46}$ Kementerian Agama RI, Al-Qur'an dan Terjemahnya, h. 337.

${ }^{47}$ See Abū al-Ḥasan 'Ali bin Muhammad bin Muhammad bin Habīb al-Bașrì al-Bagdādi alMāwardi, Al-Nukat wa al-'Uyūn, Juz IV, (Bairūt: Dār al-Küub al-'Ilmiah, t.th.), h. 32., lihat juga Abū al-Muẓaffar Manșūr bin Muḥammad bin 'Abd al-Jabbār bin Ahmad al-Marwazì al-Sam‘ānī, Tafsīr alQur'àn, Juz III, (Cet. I; Riyād: Dār al-Wațn, 1418 H/1997 M), h. 445., Abū 'Abdillah Muhammad bin 'Umar bin al-Ḥasan bin al-Ḥusain al-Tamìmi Fakhr al-Dīn al-Rāzì, Mafātịh al-Gaib, Juz 23, (Cet. III; Bairūt: Dār Ihỵà' al-Turāis al-'Arabī, 1420 H), h. 233.

${ }^{48}$ Kementerian Agama RI, Al-Qur'an dan Terjemahnya, h. 174.

${ }^{49}$ See Abū al-'Abbās Aḥmad bin Muḥammad bin Ab̄i Bakr bin 'Abd al-Malik al-Qasṭalānī, Irsyād al-Sārī li Syarh Saḥịh al-Bukhārī, Juz I, (Cet. VII; Mesir: al-Maṭba'ah al-Kubrā al-Umairiah, 1323 H), h. 144. 
understanding something. This difference in function then becomes the reason that the mind should be located in the heart. However, mind and brain are interconnected, namely the brain as a conduit of information to the mind to understand. Therefore, a heart equipped with reason function to understand something, both in terms of good or bad, benefits or harms, and so on.

\section{CLOSING}

Based on the discussion related to the hadith about the existence of the heart above, the author concludes that;

a. The hadith about existence which is the focus of the study in this paper has authentic quality, both in terms of the sanad and its matan. Moreover, with the involvement of Imam al-Bukhari and Muslims in narrating and perpetuating the hadith in their respective books.

b. The content of the hadith concerning the existence of the heart shows that the essence of the heart is a place for the treasury of all matters of an abstract nature, such as; faith, disbelief, honesty, feelings, and so on. In addition, the heart is the driving center (commanding) in the organ system of the human body and the center of Allah's judgment regarding the good or bad qualities of the human being.

After conducting a study of the hadith about the existence of the heart, the author realizes that the liver is an organ that is very small in size (a lump of flesh), but its role is huge in determining the good or bad of a person's personal quality, both physically and inactions. Therefore, the author hopes that this article can help everyone, especially Muslims, understand the existence of their hearts so that everyone can direct their hearts to goodness.

\section{REFERENCES}

'Abd al-Bāqī, Muhammad Fu’ād. Al-Mu'jam al-Mufahras li Alfäz al-Qur'ān al-Karìm. Kairo: Dār al-Kutub al-Mișriah, 1364 H.

Ahmad,Arifuddin.Paradigma Baru Memahami Hadis Nabi, (Cet. I: Jakarta: Renaisan, $2005 \mathrm{M}$.

Amin, Kamaruddin. Menguji Kembali Keakuratan Metode Kritik Hadis. Cet. I; Jakarta: Hikmah, 2009.

‘Āṭif al-Zain, Samīh. 'Ilm al-Nafs. Juz 1. Bairūt: Dār al-Kitāb al-Lubnānī, 1411 H/1991 M.

Abū 'Amr,Ibn al-Ṣalāh 'Us̀mān bin 'Abd al-Raḥman.Ma'rifah Anwā' 'Ulūm alHadis.B.Beirut: Dār al-Fikr, 1406 H/1986 M. 
M. Yusuf Assagaf, Abustani Ilyas,

Tasmin Tangngareng, La Ode Ismail Ahmad

al-Bașrì, Abū al-Fidā' Ismā'il bin 'Amr bin Kasìir al-Qurasyì.Ikhtișār 'Ulūm al-Hadì̄. Cet. II; Bairut: Dār Kutub al-'Ilmiyyah t.th..

Al-Bukhārì, Abū 'Abdillah Muhammad bin Ismā̄íl bin Mugīrah. Al-Jāmi 'al-Ṣahịh alMusnad min Hadis Rasùlillah SAW wa Sunanu-hu wa Ayyämu-hu. Juz 1 dan 2. Cet. I; Kairo: al-Maṭba'ah al-Salafiyyah, $1400 \mathrm{H}$.

al-Dārimì, Abū Muhammad 'Abdullah bin 'Abd al-Raḥman bin al-Faḍl bin Bahrām bin 'Abd al-Ṣamad al-Tamimì al-Samaraqandi. Sunan al-Dārimī. Juz 3. Cet. I; Saudi Arabiyyah: Dār al-Mugnì li al-Nasyr wa al-Tawzī', 1412 H/2000 M.

al-Gazāî, Abū Hạamid Muhammad bin Muhammad al-Ṭ̂̀sì. Ihyā 'Ulūm al-Dīn. Juz 3. Bairūt: Dar al-Ma'rifah, t.th.

Hidayati, Nur dan Dwi Retnowati. Kamus Lengkap Biologi. Cet. I; t.t.: Dwimedia Press, 2010.

al-Hurawì, Abū Manșūr Muhammad bin Aḥmad bin al-Azharì. Tahżíb al-Lugah. Juz 15. Cet. I; Bairūt: Dār Ihyāa al-Turāì al-'Arabī, 2001 H.

Ibn Manzūur, Abū al-Faụl Muhammad bin Mukrim bin 'Ali Jamāl al-Dīn al-Anșārì alIfriqi. Lisān al- 'Arab. Juz 1, 3 dan 4. Cet. III; Bairūt: Dār Șādir, 1414 H.

al-Jauziyah, Ibn Qayyim Muḥammad bin Abī Bakr bin Ayyūb bin Sa'ad Syāms al-Dīn. Al-Tibyān fì Aqsām al-Qur'ān. Bairūt: Dār al-Ma'rifah, t.th.

al-Jurjāni, 'Ali bin Muhammad bin 'Ali al-Zain al-Syarif. Al-Ta'rifäat. Cet. I; Bairūt: Dār al-Kutub al-'Ilmiah, 1403 H/1983 M.

al-Khațīb, Abd' al-Karìm. Ușūl al-Hadìs: 'Ulūmuh wa Muștalahuh. Bairūt: Dār al-Fikr, $1975 \mathrm{M}$.

Kementerian Agama RI.Al-Qur'an dan Terjemahnya. Cet. I; t.t., PT Tiga Serangkai Pustaka Mandiri, $1430 \mathrm{H} / 2009 \mathrm{M}$.

Kementerian Pendidikan Indonesia. Kamus Besar Bahasa Indonesia. Cet. XVI; Jakarta: Pusat Bahasa, $2008 \mathrm{M}$.

Majma‘ al-Lugah al-‘Arabiah. Al-Mu'jam al-Wasịt. Juz 2. Kairo: Dār al-Da'wah, t.th.

al-Māwardī, Abū al-Ḥasan 'Ali bin Muhammad bin Muḥammad bin Hạīib al-Bașrī alBagdādì. Al-Nukat wa al- 'Uyūn. Juz 4. Bairūt: Dār al-Kutub al-'Ilmiah, t.th..

al-Naisābūrí, Abū al-Ḥasan 'Ali bin Aḥmad bin Muḥamma bin 'Ali al-Wāḥidì. AlWajīz fì Tafsìr al-Kitāb al-'Azìz. Cet. I; Bairūt: Dār al-Qalam, 1415 H.

al-Naisabūri, Abū al-Ḥusain Muslim bin al-Hajjāj bin al-Qusyairī. Al-Musnad al-Ṣahịh al-Mukhtasar bi Naq1 al-'Adl 'an al-'Adl ilā Rasülillah $S A W$. Juz 3. Bairut: Dār Iṇyā al-Turäs al-'Arabì, t.th.

al-Nasā'i, Abū 'Abd al-Raḥmān Aḥmad bin Syu'aib bin 'Alì al-Khurāsānì. Al-Sunan al-Kubrā li al-Nasāi. Juz 5 dan 5. Cet. I; Bairut: Mu’assasah al-Risālah. 1421 $\mathrm{H} / 2001 \mathrm{M}$.

al-Nawawī, Abū Zakariyā Maḥyì al-Dīn Yahyā bin Syarf. Al-Minhāj Syarḥ Sahịị Muslim. Juz 11. Cet. II; Bairūt: Dār Ihyāa al-Turāis al-'Arabì, 1329 H. 
al-Qārì, Abū al-Ḥasan 'Alì bin Muhammad Nūr al-Dīn al-Malā al-Hurawì. Marqāh alMafătịh Syarh Misykāh al-Mașābīh. Juz 8. Cet. I; Bairūt: Dār al-Fikr, 1422 $\mathrm{H} / 2002 \mathrm{M}$.

al-Qasṭalānī, Abū al-'Abbās Aḥmad bin Muḥammad bin Abī Bakr bin 'Abd al-Malik. Irsyād al-Särī li Syarh Șaḥịh al-Bukhärī. Juz 1. Cet. VII; Mesir: al-Maṭba'ah alKubrā al-Umairiah, $1323 \mathrm{H}$.

al-Qazawainī, Ibn MājahAbū 'Abdillah Muhammad bin Yazìd. Sunan Ibn Mājah. Cet. I; Riyāḍ: Maktabah al-Ma'ārif li al-Nasyr wa al-Tawzi'‘ $1418 \mathrm{H}$.

al-Qusyairì, Ibn Daqiiq Taqi al-Dīn Abū al-Fath Muhammad bin 'Ali bin Wahb bin Mutịi'. Syarh al-Arba'in al-Nawawiyah fí al-Hadis al-Ṣahịhah al-Nabawiyah. Cet. VI; t.t.: Mu'assasah al-Rayyān, 1424 H/2003 M.

al-Rāzìi, Abū 'Abdillah Muhammad bin 'Umar bin al-Ḥasan bin al-Husain al-Tamīmì Fakhr al-Dīn. Mafâtịh al-Gaib. Juz 23. Cet. III; Bairūt: Dār Ihyā' al-Turāì al'Arabi, $1420 \mathrm{H}$.

al-Rāzìi, Abū al-Ḥusain Aḥmad bin Fārīs bin Zakariyā al-Quzwinī.Mu'jam Maqāyīs alLugah. Juz 3, 4 dan 5. t.t.: Dār al-Fikr, 1399 H/1979 M.

al-Sallāmì, Zain al-Dīn 'Abd al-Raḥman bin Aḥmad bin Rajab bin al-Hasan. Jāmi' al'Ulüm wa al-Hukm fí Syarh Khamsīn Hadisian min Jawämi' al-Kalim. Juz 1. Cet. VII; Bairüt: mu'assasah al-Risālah, 1422 H/2001 M.

al-Sam‘ānī, Abū al-Muzaffar Manșūr bin Muhammad bin 'Abd al-Jabbār bin Ahmad al-Marwazi. Tafsìr al-Qur’ān. Juz 3. Cet. I; Riyāḍ: Dār al-Waṭn, 1418 H/1997 M.

al-Sijistānì, Abū Dāwūd,Sulaimān bin al-‘Asy'as bin Ishāa bin Basyīr bin Syidād bin 'Amr al-Azadi. Sunan Abī Dāwūd. Juz 3. Cet. I; Bairut: Dār Ibn Hazm, 1418 H/1998 M.

Syahraeni, A. Kritik Sanad dalam Perspektif Sejarah. Cet. I; Makassar: Alauddin Press, $2011 \mathrm{M}$.

al-Syaibānī, Abū 'Abdillah, Aḥmad bin Muḥammad bin Hanbal bin Hilāl bin Asad. AlMusnad li Imām Ahmad bin Hanbal. Juz 7, 14 dan 16. Ceț I; Kairo: Dār alHaadis, 1416 H/1995 M.

al-Tirmiżì, Abū 'Abdillah Muhammad bin 'Ali al-Hākim.Bayān al-Farq bain al-Ṣadr wa al-Qalb wa al-Fu'àd wa al-Lubb. Oman: Mu'assasah Âli al-Bait al-Milkiah li al-Fikr al-Islāmī, $2009 \mathrm{M}$.

al-Turmużī, Abū 'Isā Muḥammad bin 'Isā bin Saurah.Al-Jāmi' al-Ṣaḥịh. Juz 3. Cet. II; Mesir: Syarikah Maktabah, 1388 H/1968 M. 